\title{
La transformación del estudiante universitario al profesional en ciencias de la salud
}

\section{The transformation of the university student to professional in health sciences}

\author{
Alejandra Tuljak ${ }^{1}$
}

Discurso en el del acto de "Bendición de Manos" a egresados 2020 de la Facultad de Ciencias de la Salud de la Universidad Católica de Córdoba.

1. Universidad Católica de Córdoba, Facultad de Ciencias de la Salud, Coordinadora de la Licenciatura en Terapia Ocupacional.

Correspondencia: Alejandra Tuljak. E-mail: aletuljak@hotmail.com

"Haz las cosas como si todo dependiera de ti y confía en Dios como si todo dependiera de Él"

En lo personal, esta frase me impacta: me inquieta y me transmite paz, dos sensaciones opuestas. Me inquieta por el compromiso que supone, y al mismo tiempo me llena de paz, el camino se aliviana... se disfruta cuando nos dejamos en manos de Alguien más.

Lo que viene...el cambio...el paso de ser estudiantes a ser profesionales...el desafío...

Cuanta sabiduría en estas palabras de San Ignacio de Loyola que invitan a reflexionar y a "mirar" como futuros profesionales de la salud desde la perspectiva de nuestra querida Universidad Católica Córdoba: hombres de ciencia, conciencia y compromiso; y con la confianza absoluta de quien se deja en manos de Él, de Él con mayúscula: de Dios.

Para dar inicio a este acto de "Bendición de Manos", las y los coordinadores, directores, y profesores de las carreras de Ciencias de la Salud de la Universidad Católica de Córdoba quisiéramos expresarles nuestros deseos:

Les deseamos valentía, para iniciar esta nueva etapa que se avecina.

Les deseamos felicidad y fortaleza en su desarrollo profesional: que disfruten el camino.

Les deseamos humildad y generosidad frente a sus errores y frente a sus aciertos profesionales. 
Les deseamos convicción y compromiso, para que dejen huellas, huellas que sean el reflejo del paso un nutricionista, un terapista ocupacional, un instrumentador quirúrgico, un odontólogo egresado de la UCC.

Les deseamos que sean hombres que pongan a disposición sus talentos para ser agentes de cambio, para que por donde pasen crezca pasto verde del bueno y sople viento nuevo.

Deseamos que recuerden siempre que esta es su casa, que nos recuerden como quienes acompañamos e intentamos hacer siempre lo mejor posible con nuestras limitaciones, pero siempre con buenas intenciones.

Deseamos que hoy en este acto tan significativo: "el acto de bendición de manos" con absoluta confianza dejemos nuestras manos en Sus manos, como si todo dependiera de Él, y con absoluto compromiso como si todo dependiera de ustedes en el hacer profesional, que el caso de ustedes involucrará a personas, personas que requerirán de sus conocimientos y de su humanidad.

Fundamentalmente les deseamos que este "dejar todo en la cancha" sea un aprendizaje continuo ...sea una construcción puesta al servicio de los demás.

Este extraño 2020 de pandemia nos resultará sin dudas inolvidable, para bien o para mal, y acá tengo que hacer un paréntesis para dirigirme especialmente a nuestros estudiantes de Terapia Ocupacional, y decirles que este 2020 para los profesores y coordinadoras de la carrera, que la vimos nacer, y que tanto Laura como yo, contamos con la dicha de coordinarla, este año realmente será inolvidable, y no por la pandemia per se, sino porque este año nos regala a nuestros primeros egresados Licenciados en Terapia Ocupacional de nuestra universidad, de nuestra UCC, lo menciono con inmenso orgullo y alegría... sin dudas un 2020 inolvidable.

Finalmente, decirles a todos: unas gracias, darles una "recomendación", unas felicitaciones, y un adelante.

Unas gracias por todo lo que nos enseñaron a nosotros en estos años,

Un permiso para darles una "recomendación": Que amen lo que hagan....ahí está la diferencia.

Unas felicitaciones por sus logros en este recorrido académico, y un adelante: brindamos porque sus logros se multipliquen en su vida profesional.

¡Bienvenidos a este acto y esta nueva etapa de su vida!

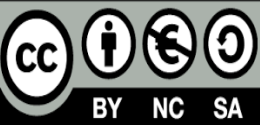

